10. Thorben Albrecht A human-centred agenda for the future of work. Social Europe. 22nd January 2019. URL: https://www.socialeurope.eu/thefuture-of-work (date of request: 15.12.19) (in English).

11. Gostyuk O. Kontseptsiya gidnoï pratsi yak element pravovoï politiki derzhavi [The concept of decent work as an element of legal policy of the state]. Pidpriemnitstvo, gospodarstvo i pravo. 2016. №6. S.90-93 (in Ukrainian).

12. Kolyada T.A. Kontseptsiya gidnoï pratsi v trudovomu pravi Ukraïni [The concept of decent work in the labor law of Ukraine]. Forum prava. 2010. №3. S.201-205 (in Ukrainian).
13. Гідна праця: політика зайнятості та оплати праці (аналітичний матеріал за результатами дослідження "Посилення внеску профспілок у забезпечення гідної праці в Україні") / В.В. Буяшенко, О.О. Кобзиста, Я.С. Ткаченко. Вісник Академії праці, соціальних відносин та туризму. 2016. №1-2. C.9-24 (in Ukrainian).

Наукове дослідження проведено в рамках держбюджетної теми №19БФ042-01M "Соціально-правові засади збереження та розвитку трудового потенціалу України"

Received: $01 / 12 / 2019$ Accepted: $26 / 12 / 2019$

I. Sakharuk, PhD (Law), Associate prof.

Taras Shevchenko National University of Kyiv, Kyiv, Ukraine

\title{
FORMATION GENESIS AND MODERN CONTENT FOR THE CONCEPT OF DECENT WORK
}

The article is aimed at researching the concept of decent work as a strategic direction of the labour legislation development in XXI century. Decent work is considered as the basis for sustainable development, overcoming poverty and income inequality. The author analyses the stages of formation and development of the concept of decent work in the International Labour Organization (ILO) activity. It also determines the content of the basic dimensions of decent work for ILO standards. There are such elements of the concept of decent work as the fundamental principles and rights at work, the promotion of productive employment, social protection, social dialogue. The need for defining qualitative and quantitative indicators to measure progress towards decent work in each country is emphasized.

The need for decent work is especially relevant in the modern period, due to the deepening of the human-oriented approach to regulating relations in the field of work. The broader content of the substance of social protection has been identified in comparison with national doctrine, including measures for social security and protection of workers, as well as working conditions. It is emphasized that nowadays the decent work is the safe work. It is concluded that social dialogue is the key to achieving the goals of decent work, balancing the interests of the state, employees and employers in the field of work.

The article summarises scientific approaches to determining the content and objectives of decent work nowadays. The purpose of the concept of decent work is defined as ensuring productive employment, decent working conditions, and opportunities for professional and personal development of employees on the basis of equality, fairness and security. It is emphasised that the complexity of the concept of decent work, the realization of this concept will affect not only labour relations, but also at the standard of living of employees and society as a whole. The implementation of international standards for the decent working conditions, decent wages, ensuring equal rights and opportunities allows improving the wellbeing of employees, their economic status, and also affects the level of the country's economic development.

Keywords: decent work, the concept of decent work, International Labor Standards, human-centered approach, fundamental principles and rights at work, social dialogue, productive employment, working conditions, social protection.

Bulletin of Taras Shevchenko National University of Kyiv Legal Studies, 2019; 4 (111): 67-74

удк: 347.91

DOI: https:doi.org/10.17721/1728-2195/2019/4.111-13
ISSN 1728-2195

(C) Taras Shevchenko National University of Kyiv,

Publishing center "Kyiv University", 2019

В. Турканова, магістр права ORCID: 0000-0002-8345-6681

Київський національний університет імені Тараса Шевченка, Київ, Україна, магістр політології та комунікацій

Лондонська школа економіки та політичних наук, Лондон, Великобританія

\section{ВІДКРИТІСТЬ І ГЛАСНІСТЬ СУДОВОГО РОЗГЛЯДУ ТА ВИКОНАННЯ СУДОВИХ РІШЕНЬ: СВІТОВІ ТА ЄВРОПЕЙСЬКІ СТАНДАРТИ НА ПРИКЛАДІ ЗАКОНОДАВСТВА АНГЛІЇ ТА УЕЛЬСУ, США І ПРАВА ЄС}

\begin{abstract}
Розкрито правову природу принципу гласності та відкритості судового розгляду і виконання судових рішень як інтегральної частини концепції права особи на справедливий суд. 3'ясовано основні підходи і світові стандарти відкрuтості та гласності виконання судових рішень, узагальнених на прикладі законодавства Англії та Уельсу, США і права ЄС, які можуть бути враховані під час подальшого реформування відповідного законодавства України. Проаналізовано термінологічні проблеми перекладу термінів "рublic hearing", "ореn court", "ореп trial" ma iнuих з огляду на їхній зміст і сутність. У результаті проведеного дослідження запропоновано реалізувати концепцію відкритого, гласного виконання судових рішень як невід'ємної частини судового розгляду, зокрема за допомогою запровадження інституту перевірки судових рішень та інших документів, що підлягають опублікуванню у встановленому законом порядку, адвокатами або уповноваженими представниками сторін справи.
\end{abstract}

Ключові слова: виконання судових рішень, виконавче провадження, доступ до правосуддя, відкритість правосуддя, цивільний процес.

ВСтуп. Вплив Загальної декларації та Європейської конвенції на розвиток законодавства європейських країн важко переоцінити - упродовж останніх семидесяти років воно трансформувалося в дусі верховенства прав людини та забезпечення права на справедливий суд. 3 огляду на це більшість країн Європи сповідують єдині підходи до визначення загальних засад здійснення судочинства та виконання судових рішень у справі. Водночас при детальнішому аналізі можна ви- явити певні особливості підходів до реалізації цих засад у законодавстві деяких країн.

Для України аналіз і врахування позитивного світового досвіду розвитку виконавчого провадження $€$ надзвичайно важливим. Під час реформування системи правосуддя у відповідних процесуальних кодексах України були істотно оновлені положення про відкритість і гласність судових проваджень у справі - це Цивільний процесуальний кодекс (далі - ЦПК) [11], Господарський 
процесуальний кодекс (далі - ГПК) [2] та Кодекс адміністративного судочинства (далі - КАС) [7]. Зокрема, у нових редакціях було уточнено положення про гласність судового розгляду та відкритість інфрормації про справу (наприклад ст. 7 "Гласність судового процесу" та 8 "Відкритість інформації щодо справи" ЦПК).

Було також ухвалено новий Закон "Про виконавче провадження" (далі - Закон про виконання) [4], статтею 2 якого було закріплено засади здійснення виконавчого провадження, серед яких гласність і відкритість здійснення виконавчого провадження в Україні. Водночас жодних конкретних положень, у яких розкривається сутність зазначеного принципу, у цьому законі немає.

Зазначене зумовлює мету нашого дослідження, а саме: з'ясувати основні підходи до відкритості та гласності виконання судових рішень у світлі світових і європейських стандартів на прикладі законодавства Англії та Уельсу, США і права ЄС, які можуть бути враховані під час подальшого реформування відповідного законодавства України.

Для порівняльного дослідження ми обрали Федеральні правила цивільного процесу Сполучених Штатів Америки (далі - ФП ЦП США) [21], а також Правила цивільного процесу Англії та Уельсу (далі - ПЦП АУ) [36] з огляду на необхідність вивчення передового світового досвіду реалізації положень про публічність захисту прав і виконання судових рішень.

У нашій статті буде також проаналізоване європейське законодавство, що врегульовує положення про Європейський виконавчий лист [31] та Європейський судовий наказ як приклади виконавчих документів, а також європейську процедуру розв'язання дрібних спорів [32], що теж містить положення про виконання ухваленого судового рішення у справі [9]. Досліджено положення про спільні мінімальні стандарти цивільного судочинства у ЄС [20], які перебувають у процесі законодавчої реалізації як приклади стандартів відкритості та гласності судочинства і виконання судових рішень у $€ С$. Проект із підготовки європейських правил цивільного процесу ELI-Unidroit, що перебуває на фінальній стадії [22; 40, с. 1], також є об'єктом нашого дослідження щодо питань публічності, гласності та відкритості здійснення судочинства й виконання судових рішень.

ВИКЛАД ОСНОВНОГО МАТЕРІАЛУ. Варто одразУ наголосити на проблемі термінологічного перекладу та певній двозначності, що простежується в нашому дослідженні, яка потребує нагального розв'язання. Терміни "публічний судовий розгляд", "прилюдний судовий розгляд", "відкритість" і "гласність", що застосовуються в національному законодавстві України, не завжди $є$ тотожними з термінами, які використовуються в національному законодавстві інших країн, а також у європейському законодавстві. 3 огляду на це в посиланнях до тексту роботи зазначається оригінал досліджуваного положення, зокрема норма статті або інші положення. Комплексне тлумачення положень доктрини та законодавства дозволяє виділити такі характеристики того чи іншого правового явища, що дають можливість судити про тотожність термінів і понять у висновку.

Зокрема, у Загальній декларації йдеться про "public hearing" та "public trial" (ст. 10 та 11) [38], що офріційно було перекладено як "прилюдно" та "прилюдний судовий розгляд", відповідно [3]. У Європейській конвенції йдеться про "public hearing" (ч. 1 ст. 6) [19], що офріційно було перекладено українською як "публічний розгляд справи" [8].
У ФП ЦП США [21] закріплено положення про "open court", як, наприклад, вимога щодо проведення судового розгляду відкрито в приміщенні суду, якщо це можливо - у звичайному залі судових засідань (ч. b правила 77). Так само, наприклад, покази свідків мають надаватися на відкритому засіданні (про концепцію "open court" у цивільному процесі Сполучених Штатів див. детальніше у [26, 35, 14, 24]).

Для забезпечення публічності судового розгляду справи закріплено вимогу визначення розкладу проведення "oral hearing": $з$ цією метою суд має встановити час та місце проведення усних слухань у справі, якщо правилами або наказом не встановлено, що суд може розглянути подане клопотання у справі без проведення усного слухання (правило 78).

Матеріали цивільної справи зберігаються відповідно до встановлених у США правил судовим клерком у вигляді "civil docket" - це матеріали справи, що включаються відповідно до правила 79 ФП ЦП США і ведуться у відповідному реєстрі (правило 79) [15], позначені послідовними номерами з першого запису у справі, включаючи: а) документи, подані клерку; b) видані у процесі з доказами вручення або іншого виконання; і с) виступи, накази, вироки та рішення.

Кожен документ має бути коротко охарактеризований: зокрема, суть кожного доказу, повідомлення, а також зміст і дата ухвалення кожного наказу та рішення. Зберігаються копії кожного остаточного рішення та наказу; кожного наказу, що впливає на право власності або заставу на нерухоме майно; будь-який інший наказ, який суд зобов'язаний зберігати.

Варто зауважити, що інформація про справу, рішення та інші матеріали справи є доступною публічно, за винятком положень щодо персональних даних осіб, які брали у ній участь.

У США врегульовано положення щодо захисту інформації стосовно персональних даних учасників судових процесів, що збирається, зберігається та/або розповсюджується. Відповідно до змін до апеляційних, цивільних та кримінальних правил щодо виконання вимог Закону про електронне урядування 2002 р., що набули чинності з 1 грудня 2007 р. [27, 28], суди, які готують електронні документи як дистанційно доступні для громадськості, повинні надати доступ адвокатам у справі переглянути їх щодо ідентифікаторів персональних даних, які, відповідно до федеральних правил, мають бути відредаговані. Упродовж семи календарних днів 3 моменту вручення судовим репортером або переписувачем офріційної розшифровки до канцелярії кожен адвокат повинен повідомити суд, подавши повідомлення про редагування або наміри керувати редагуванням щодо персональних даних з електронного протоколу судового розгляду. Якщо таке повідомлення не буде подане протягом призначеного часу, то суд прийме рішення, що редагування ідентифрікаторів персональних даних із розшифровки не $є$ необхідним.

Варто зазначити, що наразі в чинному законодавстві України відсутні такі механізми, які дозволяють доступ до документів, що підлягають опублікуванню, зокрема судові рішення у справі, що іноді призводить до порушень права особи на захист персональних даних [5].

Виконання судових рішень у США здійснюється відповідно до внутрішніх правил кожного штату, водночас, згідно з положеннями правила 69 ФЦП, рішення, що містить зобов'язання щодо сплати коштів, виконується шляхом напису про виконання, якщо суд не 
зобов'язує інше. Процедура виконання, а також будьякі допоміжні судові процедури, що провадяться з метою виконання судового рішення, мають відповідати процедурі тієї держави, у якій розташований суд; федеральний статут застосовується тією мірою, якою він регулює зазначені відносини. Зокрема, федеральними правилами встановлено положення, що на допомогу у виконанні рішення або у виконавчому провадженні кредитор у судовому порядку може вимагати відкриття інформації від будь-якої особи, включаючи боржника, за ухваленим рішенням, як це передбачено цими правилами або процедурою держави, де знаходиться суд (правило 69). Отже, законодавством урегульоване положення щодо зобов'язання боржника повідомити суду інформацію, необхідну для виконання судового рішення проти нього.

Судочинство в цивільних справах та виконання судових рішень в Англії та Уельсі здійснюється на підставах публічності й відкритості, зокрема, реалізується концепція публічно-приватного судового розгляду справи, а також відкрита інформація щодо справи і боржника та його активів для забезпечення виконання ухваленого судового рішення.

Згідно з ПЦП АУ [36], за загальним правилом судове слухання - це публічне або відкрите слухання справи або "hearing in public" (положення ч. 1 правила 39.2), що реалізується таким чином. Розгляд справи не може проводитися приватно (in private) незалежно від згоди сторін, навіть тією мірою, якою суд вирішує, що він повинен бути проведений приватно, застосовуючи такі положення:

слухання або будь-яка його частина має проводитися приватно, якщо та тільки тією мірою, якою суд вважатиме наявною одну або кілька підстав, викладених у підпунктах, і необхідно розглядати справу в закритому режимі, щоб забезпечити належне здійснення правосуддя:

a) розголошення завдасть шкоди об'єкту слухання;

b) питання стосуються національної безпеки;

c) питання стосуються конфіденційної інформації (включаючи інформацію, що стосується особистих фінансових питань) і розголошення може завдати шкоди цій конфріденційності;

d) приватне слухання необхідне для захисту інтересів будь-якої дитини або захищеної сторони (protected party);

е) це слухання заяви, зробленої без повідомлення, i було б несправедливим для будь-якого відповідача, щоб воно було публічним;

f) це стосується незаперечних питань, що виникають при адмініструванні трастів або в управлінні майном померлого;

g) суд із будь-якої іншої причини вважає це необхідним для забезпечення належного здійснення правосуддя.

Варто зауважити, що в Правилах домінує дихотомія "public hearing" та "private hearing", що означає публічні або приватні слухання справи, не торкаючись питань відкритого або закритого судового розгляду.

Термін "in open court", або "відкритий судовий розгляд", використовуються у ПЦП АУ у значенні розумних заходів для забезпечення відкритості та публічності всіх слухань, за винятком випадків, коли слухання проводиться приватно, які мають уживатися судом, про що зазначено у ч. 2 правила 39.2. При цьому під час розв'язання питання про проведення приватного слухання суд повинен мати на увазі, що жоден обов'язок або право на свободу вираження поглядів не можуть бути порушені.
Суд має наказати, щоб особа будь-якої сторони або свідка не розголошувалася, якщо і лише якщо вона вважає необґрунтованим таке розкриття в інтересах забезпечення належного здійснення правосуддя і захисту інтересів цієї сторони або свідка.

Кілька категорій справ можуть бути розглянуті приватно відповідно до ПЦП АУ, зокрема згідно з § III правила 8.1 щодо зобов'язань після смерті сторони, а також мають розглядатися приватно, якщо суд не постановить інше згідно з § IV у справах про фрінансові зловживання.

Питання щодо інформації про справу, а також будьяка комунікація із судом характеризуються відкритістю та транспарентністю. Зокрема, згідно з положеннями правила 39.8 будь-яке спілкування між стороною та судом має бути розкрито, а якщо це в письмовій формі (у паперовому або електронному форматі) - то скопійовано для іншої сторони або сторін або їхніх представників. Це правило поширюється на будь-які повідомлення, у яких ідеться про справу і які подаються до суду по суті або щодо процедури її розгляду. Виключеннями $є$ тільки повідомлення суто рутинні, безпідставні та управлінські (purely routine, uncontentious and administrative).

Фіксація судового розгляду в Англії та Уельсі ведеться так само технічними засобами, зокрема відповідно до правила 39.9 під час будь-якого слухання, як у Високому суді, так і в окружному суді, провадження записується на стрічці або цифровим способом, якщо суддя не обере інший варіант. При цьому жодна сторона або представник громадськості не може використовувати неофіційне обладнання для запису в будь-якому суді або кімнаті судді без дозволу суду, оскільки відповідно до Закону про неповагу до суду 1981 року без дозволу це $є$ неповагою до суду.

Будь-яка сторона або особа може вимагати розсилку запису або стенограму будь-якого слухання, що їм надається після сплати зборів, передбачених для оформлення запису або його розшифрування. Якщо особа, яка вимагає розшифрування або стенограми, не є стороною у справі, а слухання або будь-яка його частина відбувалися у приватному порядку, то стенограма надається за наказом суду.

Варто також зазначити, що в Англії та Уельсі судові рішення публікуються та $є$ доступними у відкритому доступі для всіх зацікавлених.

Згідно з ч. 5 правила 39.2 окрім випадків, коли суд ухвалить рішення в ході приватного слухання, копія рішення публікується на веб-сайті судової влади Англії та Уельсу (яке можна знайти на сайті www.judiciary.uk). У результаті будь-яка особа, яка не $є$ і не була стороною або учасником судового процесу, може подати заяву на участь у слуханні та/або про скасування чи зміну судового рішення.

Спеціальні положення передбачені в ПЦП АУ для отримання інформації щодо особи, яка $є$ боржником за ухваленим рішенням суду. Відповідно до правила 71.1 боржник зобов'язаний відвідати суд та надати інформацію з метою забезпечення виконання судового рішення або наказу проти нього. Відповідно для цього може вимагатися інформація про кошти боржника або будь-яка інша інформація, необхідна для виконання судового рішення або наказу. Таку заяву може розглянути судовий службовець без проведення судового слухання.

Боржник за рішенням суду має відвідати суд у час і місце, зазначені в наказі, подати до суду документи, що 
знаходяться у нього, описані в наказі; відповідати під клятвою на запитання, які може поставити суд. При цьому він має зауважити на таке повідомлення суду:

"Якщо ви, особа, названа ..., не виконаєте цього наказу, це може вважатися неповагою до суду, за що ви можете бути ув'язнені або оштрафовані або ваше майно може бути вилучено" (ч. 7 правила 77.2) [27].

Варто також зазначити, що в Англії та Уельсі контролюється інформація, що зберігається судами, зібрана ними в ході здійснення правосуддя у справі. Так, відповідно до Правил конфіденційності збирання та обробки інформації судами обробляються лише персональні дані, які $€$ важливими для здійснення правосуддя у справі [27]. Типи даних, зібрані із судових форм, можуть включати: ім'я, адресу, контактні дані, економічні обставини, етнічну приналежність, релігійні переконання та реквізити будь-яких інших осіб, включаючи дітей, яких стосуються справи, або тих, хто може мати інтерес до провадження. Персональні дані зазвичай отримуються безпосередньо від осіб, які беруть участь у справі, або від іншої особи, яка включила ці дані в судову форму, яку заповнила. Особисті дані також можуть бути отримані 3 інших джерел упродовж усього провадження, наприклад від професійних організацій, місцевої влади, поліції або іншої сторони у справі.

Персональні дані збираються для здійснення правосуддя і підтримки незалежної судової влади у відстоюванні верховенства права та справедливому, швидкому й ефективному виконанні правосуддя. Усі дані, необхідні для цієї мети, збираються та зберігаються у судових формах, які завантажуються до бази даних суду, що здійснює правосуддя у справі, використовуються персоналом суду з метою ведення справи і збирання інформації про її рух.

Такі судові форми були розроблені для використання в цивільному процесі з метою забезпечення ефективного розгляду судових справ (case management) [1; 6]. Форми зазвичай використовуються для ініціювання розгляду справи або виконання процесуальних дій у ході існуючих процедур, а надана інформація дозволяє суду здійснювати правосуддя й ухвалювати рішення. Як зазначено вище, закони про захист даних застосовуються до суду по-різному, коли особисті дані збираються i використовуються під час провадження. Дані, отримані в цивільних судових справах, використовуються для статистичних цілей, а також анкетування щодо задоволеності користувачів суду та питань його покращення.

У праві ЄС прямо йдеться про публічність судового розгляду як основну засаду здійснення правосуддя. Зокрема, у ст. 47 Хартії основних прав Європейського Союзу (далі - Хартія) [10] зазначено, що кожен, чиї права і свободи, гарантовані законодавством Союзу, порушуються, має право на ефективний засіб правового захисту в суді відповідно до умов, викладених у цій статті; кожен має право на справедливий і публічний розгляд упродовж розумного терміну незалежним і безстороннім судом, попередньо встановленим законом; кожен має можливість користуватися порадами і бути обізнаним, захищеним і представленим (ст. 47).

Термін "being advised" варто тлумачити достатньо широко, у контексті не тільки представництва своїх інтересів адвокатом, але й бути поінформованим особисто про інформацію, необхідну для захисту власних прав. Відповідно у Хартії більш комплексно вирішується питання щодо публічності та відкритості інформації стосов- но справи, а також правил, що застосовуються для іії розгляду, і виконання ухваленого судового рішення.

У загальноєвропейських процедурах, зокрема 3 видачі Європейського виконавчого листа [31; 9], містяться вимоги до забезпечення відкритості інформації, яку держави-члени повинні надати громадськості та професійним колам про: а) способи та процедури виконання у державах-членах; b) компетентні органи 3 виконання в державах-членах (ст. 29), застосовуючи для цього, зокрема, Європейську судову мережу в цивільних і комерційних справах.

Більше правил щодо відкритості інформації про процедуру та виконання ухвалених судових рішень установлено у процедурі видачі Європейського судового наказу [30; 9], зокрема щодо інформації про витрати на повідомлення або вручення документів та виконання наказу, а також які органи компетентні виконати судовий наказ (ст. 28).

Процедурою розв'язання дрібних спорів передбачено можливість розгляду і розв'язання справи, а також ухвалення рішення, що може бути виконане в будь-якій 3 держав-членів ЄС, відповідно до узагальнених правил, що прямо застосовуються судами [32].

Відповідно до загальних засад застосування цієї процедури суд віддає пріоритет письмовій процедурі, від якої можна відійти, тільки якщо суд або орган, або сторона, яка цього вимагає, вважає необхідним проведення усного слухання у справі, з огляду на право на справедливий судовий розгляд і принцип змагальності судочинства. При цьому положеннями регламенту держави-члени прямо зобов'язані заохочувати учасників до використання сучасних комунікаційних технологій для проведення усного слухання у справі (ст. 8).

Водночас суд може відмовити в такому запиті, якщо вважає, що, з огляду на обставини справи, усне слухання не $є$ необхідним для її справедливого розгляду (ст. 5).

Держави-члени зобов'язані надавати інформацію про те, як розпочати процедуру (ст. 4), оскаржити ухвалене в порядку цієї процедури рішення (ст. 17), а також щодо витрат (ст. 24), юрисдикції судів з розгляду заяв, поданих у порядку цієї процедури, способів комунікації, які доступні в судах, можливості оскаржити ухвалене рішення та суд, до якого можна звернутися, а також мови, що доступні, і органи, що уповноважені виконувати ухвалене рішення (ст. 25).

Варто зазначити, що всі проаналізовані вище процедури оснащені відповідними формами, які дозволяють у спрощеному та дистанційному порядку звернутися до компетентного суду

Варто зауважити, що всі європейські акти містять вимоги до відкритості інформації про суди, компетентні розглядати конкретні заяви та ухвалювати рішення, а також органи, які уповноважені виконувати ухвалені рішення, включаючи способи комунікації, доступні в цих судах та органах, мови тощо. Така інформація розміщена на порталі судової влади ЄС e-Justice [16; 17] з урахуванням правил щодо захисту персональних даних [33].

Відповідно до положень Резолюції щодо спільних мінімальних стандартів цивільного процесу в $€ С$, що була ухвалена Європейським парламентом 4 липня 2017 р. (далі - Резолюція) [20] для забезпечення права осіб бути почутими судом, не вимагаючи від них дістатися суду або органу, держави-члени повинні забезпечити проведення усних слухань у справі, а також дослідження таких доказів, як покази свідків, експертів або сторін, що могли бути здійснені з вико- 
ристанням будь-яких засобів дистанційного зв'язку, якщо, з огляду на конкретні обставини справи, використання такої технології не буде непридатним для справедливого розгляду справи.

У положеннях ст. 5 Резолюції зазначено, що держави-члени повинні забезпечити справедливий розгляд справи, отже, якщо сторони не можуть бути фрізично присутніми або якщо домовилися між собою та за згодою суду застосовувати прискорені засоби комунікації, то держави-члени забезпечують, щоб усні слухання проводилися шляхом використання будь-яких відповідних дистанційних комунікаційних технологій, таких як відео- або телеконференції, доступних для суду або органу.

Засада публічності здійснення судочинства закріплена у ст. 22 Резолюції, у якій ідеться про обов'язок держав-членів забезпечити відкритість судового розгляду, якщо суд не вирішить зробити їх конфіденційними, у міру необхідності, в інтересах однієї зі сторін або інших осіб або в інтересах правосуддя або дотримання громадського порядку.

Термін "confidential" не часто використовується в літературі [12; 18; 25; 39].

Підготовлена робочою групою проекту Європейських правил цивільного процесу European Law InstituteUnidroit) частина ${ }^{2}$ [22; 40; 13], що стосується принципів цивільного процесу, містить окремий параграф F "Oral, written and public Proceedings" (далі - Проект Правил), що присвячений положенням про публічне судочинство та усний i/або письмовий характер провадження у справі. Зокрема, публічність судочинства пропонується визначити як відкрите проведення слухання справи та проголошення рішення суду, включаючи мотиви його ухвалення, повинні зазвичай, на відміну від "in private", за наказом суду з міркувань державної безпеки, включаючи національну безпеку, конфіденційність або професійну таємницю, включаючи конфіденційність бізнесу або в інтересах здійснення правосуддя, частини, особливо усного засідання, або всього провадження у справі. Отже, судові рішення та мотиви їх ухвалення мають бути доступними для громадськості тією мірою, якою провадження відкрито; коли слухання відбуваються у закритому порядку, оприлюднення рішення може обмежуватися його частиною.

Матеріали справи та записи у Проекті Правил пропонується зробити доступними для громадськості принаймні для тих осіб, які мають інтерес до них, і для осіб, які здійснюють законний запит. Персональні дані сторін, свідків та інших фрізичних осіб, згаданих у рішенні, пропонується утаємничити, якщо це є абсолютно необхідним.

Відповідно до загального правила пропонується всі заяви та клопотання подавати спочатку в письмовій формі (суд також може доручити свідкам та експертам подати письмові заяви), водночас дозволити суду доручити сторонам представити усні аргументи та проводити усне опитування свідків або експертів. Якщо сторона просить про це, то суд має дозволити усне обговорення і може дозволити усне опитування. У відповід-

\footnotetext{
2 Проєкт із підготовки Європейських правил цивільного процесу, що здійснюється спільно інститутами ELI та Unidroit, триває з 2013 року. Зокрема, у вересні 2019 року була презентована консолідована версія Правил, підготовлених робочими групами, що подається на затвердження відповідними комітетами зазначених організацій. Водночас вони варті дослідження з огляду на масштабність та важливість цього проекту. Зокрема, проміжні результати, оприлюднені на міжнародних конференціях, широко обговорюються в науковій спільноті та літературі.
}

них випадках провадження може бути проведене з використанням будь-яких доступних засобів інформаційних та комунікаційних технологій.

Таким чином, у запропонованому консолідованому Проекті Правил, що пропонуються до ухвалення, поперше, відчутна концепція пріоритету публічного провадження у справі, натомість суд уповноважений з'ясувати межі та підстави необхідності проведення закритого провадження або засідання у справі; так само рішення у справах та матеріали справи пропонується зробити відкритими для доступу осіб, які мають інтерес у справі, тобто обмежити участь громадськості у контролі за здійсненням судочинства. Водночас не гарантується однозначно захист персональних даних осіб, які беруть участь у справі та можуть бути згадані в матеріалах.

Інформування сторін про виконавче провадження, у якому вони задіяні, та правила його здійснення $€$ важливою частиною забезпечення ефективного функціонування системи правосуддя в державі загалом та виконання судових рішень зокрема. Варто зауважити, що доленосні рішення ЄСПЛ щодо визнання невиконання судових рішень порушенням положень ст. 6 Європейської конвенції спонукали Раду Європи до більш рішучих дій, спрямованих на удосконалення національних систем виконання держав-членів, зокрема підготовки Рекомендації Комітету міністрів Ради Європи державамчленам щодо примусового виконання, ухвалених 9 вересня 2003 р. на 851-му засіданні (далі - Рекомендації щодо виконання) [29].

Згідно із зазначеними Рекомендаціями примусове виконання судового рішення $€$ невід'ємною частиною основоположного права людини на справедливий судовий розгляд упродовж розумного часу, закріпленого у ст. 6 Європейської конвенції, тому примусове виконання має здійснюватися на підставі норм відповідного права й судових рішень. Норми законодавства мають бути достатньо детальними, щоб процедура примусового виконання характеризувалася правовою передбачуваністю та прозорістю, а також, наскільки це можливо, прогнозованістю й ефрективністю.

У продовження реалізації зазначених Рекомендацій спеціальною комісією було підготовлено Керівництво щодо кращого впровадження чинних рекомендацій Ради Європи щодо примусового виконання (далі - Керівництво) [37]. Метою зазначеного Керівництва $є$ забезпечення ефективності реалізації європейських стандартів примусового виконання, визначене в Рекомендації щодо виконання. 3 огляду на це питання примусового виконання розглядаються в них в аспекті інтегрованого, всеохоплюючого погляду стосовно принципів, що регулюють виконання, а також тих, що становлять інтерес для фахівців, відповідальних за їх упровадження, до загальної дискусії. Узяті разом 82 пункти Керівництва покликані закласти основу для системи правозастосування, яка забезпечує правильний баланс між правами кредиторів і боржників у державах-членах Ради Європи.

Зокрема, державам-членам настійно рекомендується складати спільні європейські стандарти якості стосовно інформації, яка має бути надана сторонам і широкій громадськості, щодо процедур виконання з метою забезпечення контролю якості виконання виконавчого провадження, зокрема шляхом щорічного оцінювання ефективності роботи виконавців через незалежну систему перевірки та випадкової перевірки на місці. Щодо збирання даних і створення національної статистичної системи, беручи до уваги, якщо це можливо, Схему 
оцінювання CEPEJ та основні дані правосуддя, визначені CEPEJ, дані мають базуватися на репрезентативних вибірках і бути опубліковані. Зазначене значно сприятиме зміцненню довіри між державами-членами, особливо з огляду на перспективу збільшення кількості міжнародного примусового виконання.

Згідно з вимогами Практичного керівництва з виконання судових рішень, які були ухвалені на 26-й пленарній сесії CEPEJ 10-11 грудня 2015 р. (далі - Практичне керівництво) [23], інформування сторін виконавчого провадження має здійснюватися з тією метою, щоб вони повністю зрозуміли процес виконання, а саме про чинне законодавство та процеси виконання, у якому вони беруть участь, а також зрозумілості чинного законодавства щодо існуючих процедур та витрат.

Відповідно до зазначеного Практичного керівництва законодавство має передбачати правила оприлюднення вартості діяльності виконавців, які є ключовим компонентом загальних витрат на виконання, що існують у багатьох європейських державах, але іноді занадто складні, а також інформування сторін про процеси виконання, у яких вони беруть участь. У багатьох європейських державах існують етичні правила та/або професійні стандарти, що стосуються відносин між судовими виконавцями і кредиторами та боржниками, серед іншого з повідомленням про стадію, якої досягла процедура виконання. Детальніші положення щодо механізмів інформування осіб, яких стосуються примусові заходи, містяться в законодавстві або нормативних актах щодо таких заходів. Наприклад, боржники зазвичай інформуються про наслідки, якщо вони не вживають заходів, і засоби правового захисту, які їм доступні.

ВИСНОВкИ. Узагальнюючи результати дослідження, зробимо висновок, що в законодавстві США та Англії й Уельсу містяться положення про публічність проведення судового розгляду, зокрема судового засідання у справі, а також відкритість інформації про справу. Зокрема, у законодавстві США реалізується концепція "hearing in public" v. "hearing in private", що означає вимогу проведення відкритого судового засідання у справі, якщо відсутні підстави для проведення судового засідання тільки за участі сторін та учасників справи, тобто закритого судового засідання для осіб, що не беруть участі у справі.

Визначальна роль суду у визначенні конкретних підстав для обмеження принципу публічності судового розгляду полягає в тому, щоб він визначив, чи дійсно обставини справи можуть зашкодити інтересам правосуддя, якщо будуть розглядатися відкрито. Явище, позначене терміном "oral hearing", сприяє реалізації права особи бути почутим судом і більше відповідає принципу гласності судового процесу.

Ідентичними правовими явищами узагальнено можна вважати концепцію "public hearing" та відкритого судового засідання у справі або відкритого судового розгляду, а також "hearing in private" та закритого судового засідання у справі або закритого судового розгляду справи.

Відкрита інформація про справу має водночас бути підконтрольною сторонам з метою недопущення порушень права на захист персональних даних, зокрема за допомогою запровадження інституту перевірки судових рішень та інших документів, що підлягають опублікуванню у встановленому законом порядку, адвокатами або уповноваженими представниками сторін справи.
Список використаних джерел:

1. Ван Реє К. Case management у Європі: сучасні підходи до реапізації у цивільному судочинстві. Судова апелящія, № 3(52)., 2018. С. 95-114.

2. Господарський процесуальний кодекс України від 06 листопада 1991 року (в редакції Закону України від 03 жовтня 2017 року). URL: https://zakon.rada.gov.ua/laws/show/1798-12/print (дата звернення: 20.12.19)

3. Загальна декларація прав людини. URL: http://www.un.org.ua/ images/documents/3722/Загальна\%20декларація\%20прав\%20людини (дата звернення: 20.12.19)

4. Закон України "Про виконавче провадження" від 02 червня 2016 року. URL: https://zakon.rada.gov.ua/laws/show/1404-19/print (дата звернення: 20.12.19)

5. Захист персональних даних: правове регулювання та практичні аспекти. Практичний посібник. URL: https://rm.coe.int/168059920с (дата звернення: 20.12.19)

6. Ізарова І., Вебрайте В., Флейшар P. Case management в цивільному судочинстві: порівняльне дослідження законодавства Литви, Польщі й України. Право України. 2018. №10. С.129-146.

7. Кодекс адміністративного судочинства України. від 06 листопада 2005 року. URL: https://zakon.rada.gov.ua/laws/show/2747-15/print (дата звернення: 20.12.19)

8. Закон України "Про ратифрікацію Конвенції про захист прав і основоположних свобод 1950 року, Першого протоколу і протоколів № 2,4,7 та 11 до Конвенції". URL: https://zakon.rada.gov.ua/laws/show/ 995_004 (дата звернення: 20.12.19)

10. Науково-практичний коментар до цивільного процесуального законодавства Європейського Союзу: Частина 2 / Кол. авт. І. О. Ізарова, Р.Ю. Ханик-Посполітак, Н.Ю. Панич, А.С Ковтун. Ізарова І. О. (заг. ред.). Київ : ВД "Дакор", 2018, 568 с.

11. Хартія основних прав Європейського Союзу від 07 грудня 2000 року. URL: https://www.europarl.europa.eu/charter/pdf/text en.pdf (дата звернення: 20.12.19)

12. Цивільний процесуальний кодекс України від 18 березня 2004 року (в редакції Закону України від 03 жовтня 2017 року). URL: https://zakon.rada.gov.ua/laws/show/1618-15/print

13. Arthur R. Miller Confidentiality, Protective Orders and Public Access to the Courts, Harvard Law Review Vol. 105, № 2 (Dec., 1991), Pp. 427-502.

14. Van Rhee C.H. Civil Procedure Beyond National Borders, Access to Justice in Eastern Europe. No1 (1), 2018, Pp. 15-34

15. Callahan Charles C., Ferguson Edwin E. Evidence and the New Federal Rules of Civil Procedure , Yale Law Journal, № 5 (622) (19351936), Pp. 194-213.

16. Court Records. URL: https://www.uscourts.gov/court-records (дата звернення: 20.12.19)

17. European justice. URL: https://beta.e-justice.europa.eu/?action= home\&plang=en_(дата звернення: 20.12.19)

18. E-justice. URL: https://e-justice.europa.eu/home.do?action= home\&plang=en_(дата звернення - 10 січня 2020 року)

19. Edward F. Sherman Confidentiality in ADR Proceedings: Policy Issues Arising from the Texas Experience // Texas Law Review, 1997, № 38, Pp. 541-542.

20. European Convention in Human Rights. URL: https://www.echr.coe.int/ Documents/Convention_ENG.pdf (дата звернення: 20.12.19)

21. European Parliament resolution of 4 July 2017 with recommendations to the Commission on common minimum standards of civil procedure in the European Union. URL: http://www.europarl.europa.eu/ doceo/document/TA-8-2017-0282_EN.html (дата звернення: 20.12.19)

22. Federal Rules of Civil Procedure, as 01 December 2018 URL: https://www.uscourts.gov/rules-policies/current-rules-practice-procedure/ federal-rules-civil-procedure_(дата звернення: 20.12.19)

23. From Transnational Principles to European Rules of Civil Procedure, ELI-Unidroit. URL: https://www.europeanlawinstitute.eu/projectspublications/current-projects-feasibility-studies-and-other-activities/currentprojects/civil-procedure/ (дата звернення: 20.12.19)

24. Good practice guide on enforcement of judicial decisions as adopted at the $26^{\text {th }}$ CEPEJ Plenary Session 10-11 December 2015. URL: https://rm.coe.int/european-commission-for-the-efficiency-of-justice-cepejgood-practice-/16807477bf (дата звернення: 20.12.19)

25. Resnik J. The Privatization of Process: Requiem for and Celebration of the Federal Rules of Civil Procedure at 75 University of Pennsylvania Law Review Vol. 162, No. 7, 2014, Pp. 1793-1838.

26. Kratky L. Dore Secrecy by Consent: The Use and Limits of Confidentiality in the Pursuit of Settlement 74 Notre Dame Law Review, № 283, (1998-1999). URL: https://scholarship.law.nd.edu/cgi/viewcontent.cgi? article=1627\&context=ndlr (дата звернення: 20.12.19)

27. Louisell D. W. Confidentiality, Conformity and Confusion: Privileges in Federal Court. Tulane Law Review, №31, Pp. 101-112 (1956-1957).

28. Privacy notice for Civil Court forms. URL: https://assets.publishing.service.gov.uk/government/uploads/system/upload s/attachment_data/file/710749/Civil_privacy_notice_05218.pdf (дата звернення: 20.12.19)

29. Privacy Policy for Electronic Case Files. URL: https://www.uscourts.gov/ rules-policies/judiciary-policies/privacy-policy-electronic-case-files (дата звернення: 20.12.19) 
30. Recommendation $\operatorname{Rec}(2003) 17$ of the Committee of Ministers to member states on enforcement (adopted by the Committee of Ministers on 9 September 2003 at the $851^{\text {st }}$ meeting of the Ministers' Deputies. URL: https://search.coe.int/cm/Pages/result_details.aspx?Objectld=09000016805 df0c1 (дата звернення: 20.12.19)

31. Regulation (EC) No 1896/2006 of the European Parliament and of the Council of 12 December 2006 creating a European order for payment procedure. URL: http://eur-lex.europa.eu/legal-content/EN/ALL/?uri= CELEX\%3A32006R1896 (дата звернення: 20.12.19)

32. Regulation (EC) No 805/2004 of the European Parliament and of the Council of 21 April 2004 creating a European Enforcement Order for uncontested claims. URL: https://eur-lex.europa.eu/legal-content/EN/ ALL/?uri=CELEX:32004R0805 (дата звернення: 20.12.19)

33. Regulation (EC) No 861/2007 of the European Parliament and of the Council of 11 July 2007 establishing a European Small Claims Procedure. URL: https://eur-lex.europa.eu/legal-content/EN/ALL/?uri=celex: 32007R0861 (дата звернення: 20.12.19)

34. Regulation (EU) $2016 / 679$ of the European Parliament and of the Council of 27 April 2016 on the protection of natural persons with regard to the processing of personal data and on the free movement of such data, and repealing Directive 95/46/EC (General Data Protection Regulation) URL: https://eur-lex.europa.eu/eli/reg/2016/679/oj (дата звернення: 20.12.19)

35. Richard L. Marcus The Discovery Confidentiality Controversy URL: https://repository.uchastings.edu/cgi/viewcontent.cgi?article $=1437$ \& context=faculty_scholarship/ (дата звернення: 20.12.19)

36. Stephen N. Subrin How Equity Conquered Common Law: The Federal Rules of Civil Procedure in Historical Perspective, University of Pennsylvania Law Review Vol. 135, No. 4, 1987., Pp. 909-1002.

37. The Civil Procedure Rules 1998. URL: http://www.justice.gov.uk/ courts/procedure-rules/civil/rules (дата звернення: 20.12.19)

38. The Guidelines for a better implementation of the existing Council of Europe recommendation on enforcement (CEPEJ(2009), 11REV2, 17 December 2009, adopted by the CEPEJ at its 14th plenary meeting, in Strasbourg, on 9 and 10 December 2009 URL: https://rm.coe.int/16807473cd (дата звернення: 20.12.19)

39. The Universal Declaration of Human Rights.10.12.1948 URL: https://www.un.org/en/universal-declaration-human-rights/ (дата звернення: 20.12.19)

40. Thomas S. Leatherbury, Mark A. Cover Keeping Public Mediation Public: Exploring the Conflict between Confidential Mediation and Open Government URL: https://scholar.smu.edu/cgi/viewcontent.cgi?referer= https://www.google.com/\&httpsredir=1\&article=2326\&context=smulr. (дата звернення: 20.12.19)

41. Uzelac A. Towards European Rules of Civil Procedure: Rethinking Procedural Obligations. Hungarian Journal of Legal Studies. Acta Juridica Hungarica,№58, 2017; 3-18 doi:10.1556/2052.2017.58.1.1

\section{References:}

1. Van Rhee C.H. Case management u Yevropi: suchasni pidkhody do realizatsii u tsyvilnomu sudochynstvi. [Case management in Europe: current approaches to civil litigation implementation] Sudova apeliatsiia. № 3(52), 2018. , 2018, Ss. 95-114. (in Ukrainian)

2. Hospodarskyi protsesualnyi kodeks Ukrainy. 06.11.1991.URL: https://zakon.rada.gov.ua/laws/show/1798-12/print (in Ukrainian)

3. Zagal'na deklaratsiya prav lyudini. General'na Asambleya OON. 1948. Ofits. Tekst. St. 18 URL: http://www.un.org.ua/images/documents/ 3722/Zahalna\%20deklaratsiia\%20prav\%20liudyny(in Ukrainian)

4. Zakon Ukrainy "Pro vykonavche provadzhennia". URL: https://zakon.rada.gov.ua/laws/show/1404-19/print

5. Zakhyst personalnykh danykh: pravove rehuliuvannia ta praktychni aspekty. Praktychnyi posibnyk. [Protection of personal data: legal regulation and practical aspects: scientific and practical guide] URL: https://rm.coe.int/ 168059920c (in Ukrainian)

6. Izarova I., Vebraite V., Fleishar R. Case management v tsyvilnomu sudochynstvi: porivnialne doslidzhennia zakonodavstva Lytvy, Polshchi y Ukrainy [Case management in civil litigation: a comparative study with Lithuanian law, Poland in Ukrain] // Pravo Ukrainy, № 10, 2018, S. 129-146. (in Ukrainian)

7. Kodeks administratyvnoho sudochynstva Ukrainy. URL: https://zakon.rada.gov.ua/laws/show/2747-15/print

8. Zakon Ukrainu pro ratuficatziyu konfensii pro zachust prav lydunu ta osnovolognuch svobod [European Convention on Human Rights]. URL: https://zakon.rada.gov.ua/laws/show/995_004 (in Ukrainian)

10. Naukovo-praktychnyi komentar do tsyvilnoho protsesualnoho zakonodavstva Yevropeiskoho Soiuzu : Chastyna 2 / [Scientific and practical commentary on civil procedural law of Ukraine of the European Union] Kol. avt. I. O. Izarova, R.lu. Khanyk-Pospolitak, N.lu. Panych, A.S Kovtun. Izarova I. O. (zah. red.). Kyiv : VD "Dakor", 2018, 568 s. (in Ukrainian)

11. Khartiia osnovnykh prav Yevropeiskoho Soiuzu. [Charter of Fundamental Rights of the European Union] URL: https://www.europarl.europa.eu/charter/pdf/text en.pdf (in Ukrainian)

12. Tsyvilnyi protsesualnyi kodeks Ukrainy. [the Code of Civil Procedure of Ukraine] URL: https://zakon.rada.gov.ua/laws/show/1618-15/ print (in Ukrainian)
13. Arthur R. Miller Confidentiality, Protective Orders, and Public Access to the Courts, Harvard Law Review, Vol. 105, No. 2, (Dec., 1991), Pp. 427-502. (in English)

14. C H Van Rhee, Civil Procedure Beyond National Borders, Access to Justice in Eastern Europe, No 1, 2018, Pp. 15-34. (in English)

15. Charles C. Callahan and Edwin E. Ferguson Evidence and the New Federal Rules of Civil Procedure, Yale Law Journal, No 5, Pp. 622, 19351936. (in English)

16. Court Records. URL: https://www.uscourts.gov/court-records (in English)

17. European justice. URL: https://beta.e-justice.europa.eu/?action= home\&plang=en (in English)

18. E-justice. URL: https://e-justice.europa.eu/home.do?action=home\& plang=en (in English)

19. Edward F. Sherman Confidentiality in ADR Proceedings: Policy Issues Arising from the Texas Experience // 38 S. Texas Law Review 541 (1997). (in English)

20. European Convention in Human Rights. URL: https://www.echr.coe.int/Documents/Convention_ENG.pdf

21. European Parliament resolution of 4 July 2017 with recommendations to the Commission on common minimum standards of civil procedure in the European Union. URL: http://www.europarl.europa.eu/ doceo/document/TA-8-2017-0282 EN.html (in English)

22. Federal Rules of Civil Procedure, eff. Dec. 1, 2018. URL: https://www.uscourts.gov/rules-policies/current-rules-practice-procedure/ federal-rules-civil-procedure_(in English)

23. From Transnational Principles to European Rules of Civil Procedure ELI-Unidroit. URL: https://www.unidroit.org/work-in-progress-eli-unidroiteuropean-rules https://www.europeanlawinstitute.eu/projects-publications/ current-projects-feasibility-studies-and-other-activities/current-projects/civilprocedure/ (in English)

24. Good practice guide on enforcement of judicial decisions as adopted at the 26 $6^{\text {th }}$ CEPEJ Plenary Session 10-11 December 2015. URL: https://rm.coe.int/european-commission-for-the-efficiency-of-justicecepej-good-practice-/16807477bf (in English)

25. Judith Resnik The Privatization of Process: Requiem for and Celebration of the Federal Rules of Civil Procedure. University of Pennsylvania Law Review, Vol. 162, No. 7, 2014, Pp. 1793-1838. (in English)

26. Laurie Kratky Dore Secrecy by Consent: The Use and Limits of Confidentiality in the Pursuit of Settlement, Notre Dame Law Review, No 74, Pp. 283-285, 1998-1999. (in English)

27. Louisell D. W. Confidentiality, Conformity and Confusion: Privileges in Federal Court Today. Tulane Law Review, №31, Pp. 101-112 (19561957). (in English)

28. Privacy notice for Civil Court forms. URL: https://assets.publishing.service.gov.uk/government/uploads/system/upload s/attachment_data/file/710749/Civil_privacy_notice_05218.pdf (in English)

29. Privacy Policy for Electronic Case Files. URL: https://www.uscourts.gov/rules-policies/judiciary-policies/privacy-policyelectronic-case-files (in English)

30. Recommendation $\operatorname{Rec}(2003) 17$ of the Committee of Ministers to member states on enforcement (adopted by the Committee of Ministers on 9 September 2003 at the $851^{\text {st }}$ meeting of the Ministers' Deputies. URL: https://search.coe.int/cm/Pages/result_details.aspx?Objectld=09000016805 df0c1 (in English)

31. Regulation (EC) No 1896/2006 of the European Parliament and of the Council of 12 December 2006 creating a European order for payment procedure. URL: http://eur-lex.europa.eu/legal-content/EN/ALL/?uri=CELEX\% 3A32006R1896

32. Regulation (EC) No 805/2004 of the European Parliament and of the Council of 21 April 2004 creating a European Enforcement Order for uncontested claims. URL: https://eur-lex.europa.eu/legal-content/EN/ALL/ ?uri=CELEX:32004R0805 (in English)

33. Regulation (EC) No 861/2007 of the European Parliament and of the Council of 11 July 2007 establishing a European Small Claims Procedure. URL: https://eur-lex.europa.eu/legal-content/EN/ALL/?uri=celex: 32007R0861

34. Regulation (EU) 2016/679 of the European Parliament and of the Council of 27 April 2016 on the protection of natural persons with regard to the processing of personal data and on the free movement of such data, and repealing Directive 95/46/EC (General Data Protection Regulation). URL: https://eur-lex.europa.eu/eli/reg/2016/679/oj (in English)

35. Richard L. Marcus The Discovery Confidentiality Controversy URL: https://repository.uchastings.edu/cgi/viewcontent.cgi?article=1437\&context= faculty scholarship/ (дата звернення 10 січня 2020 року). (in English)

36. Stephen N. Subrin How Equity Conquered Common Law: The Federal Rules of Civil Procedure in Historical Perspective, University of Pennsylvania Law Review, Vol. 135, No. 4, 1987, Pp. 909-1002.

37. The Civil Procedure Rules 1998. URL: http://www.justice.gov.uk/ courts/procedure-rules/civil/rules (in English)

38. The Guidelines for a better implementation of the existing Council of Europe recommendation on enforcement (CEPEJ(2009), 11REV2, 17 December 2009, adopted by the CEPEJ at its 14th plenary meeting, in Strasbourg, on 9 and 10 December 2009 https://rm.coe.int/16807473cd (in English) 
39. The Universal Declaration of Human Rights. URL: https://www.un.org/en/universal-declaration-human-rights/

40. Thomas S. Leatherbury, Mark A. Cover Keeping Public Mediation Public: Exploring the Conflict between Confidential Mediation and Open Government URL: https://scholar.smu.edu/cgi/viewcontent.cgi?referer= https://www.google.com/\&httpsredir=1\&article=2326\&context=smulr. (дата звернення 10 січня 2020 року) (in English)

V. Turkanova, LI.M. (Law)

Taras Shevchenko National University of Kyiv, Kyiv, Ukraine,

MSc in Politics and Communication

London School of Economics and Political Science (LSE), London,United Kingdom

\section{INTERNATIONAL AND EUROPEAN STANDARDS FOR OPENNESS AND TRANSPARENCY \\ OF THE TRIAL AND THE ENFORCEMENT OF JUDICIAL DECISIONS (ON THE EXAMPLE OF THE LEGISLATION OF ENGLAND AND WELLS, THE USA AND THE EU)}

The article reveals the legal nature of the principle of openness and transparency of a trial and the enforcement of judgments as an integral part of the concept of a person's right to a fair trial. The purpose of our study is to find out the main approaches to the openness and transparency of the enforcement of judgments in the light of international and European standards, such as the laws of England and Wales, the US and EU law. For our comparative study, the United States Federal Rules of Civil Procedure and Civil Procedure Rules of England and Wales have been selected in view of the need to study the world's best practices. The European legislation governing the provisions of the European Enforcement Order and the European Order for Payment and European Small Claims Procedure, are among the objects of our study. Provisions on common minimum standards for civil procedure in the EU, which are in the process of legislative implementation, are examined as examples of the standards of openness and transparency of justice and enforcement of judgments in the EU. They are also among the sources of our study on, transparency and openness in the administration of justice and the enforcement of judgments.

In this article the terminological problems of translation of the terms "public hearing", "open court", "open trial" and others relative terms are analyzed in depth, based on their legal content and essence.

As a result of the research, the concept of open enforcement of court decisions as an integral part of court proceedings is proposed to implement, in particular, by introducing the institution of review of court decisions and other documents subject to publication in accordance with the procedure established by law, attorneys or agents affairs.

Keywords: enforcement of judgments, enforcement proceedings, access to justice, openness of justice, civil procedure. 